\title{
To the Calculation of the Compatibility of Oligomers with High Molecular Weight Rubbers
}

\author{
Vasily D. Voronchikhin*a, Mikhail S. Tovbis ${ }^{a}$, \\ Svetlana Yu. Voronina ${ }^{a, b}$ and Olga V. Karmanova ${ }^{\mathbf{c}}$ \\ ${ }^{a}$ Reshetnev Siberian State University of Science and Technology \\ Krasnoyarsk, Russian Federation \\ ${ }^{b} F R C$ «Krasnoyarsk Science Center SB RAS» \\ Krasnoyarsk, Russian Federation \\ 'Voronezh State University Engineering Technology \\ Voronezh, Russian Federation
}

Received 08.12.2019, received in revised form 12.12.2019, accepted 12.02.2020

Abstract. The article presents a modified theoretical calculation of the solubility parameter for oligomers and polymers, taking into account the influence of their molecular structure. The obtained values of the solubility parameter make it possible to predict thermodynamic compatibility for polymers and oligomers.

Keywords: solubility parameter, polymers, oligomers, thermodynamic compatibility.

Citation: Voronchikhin V.D., Tovbis M.S., Voronina S.Yu., Karmanova O.V. To the calculation of the compatibility of oligomers with high molecular weight rubbers, J. Sib. Fed. Univ. Chem., 2020, 13(1), 31-39. DOI: 10.17516/1998-2836-0167

(C) Siberian Federal University. All rights reserved

This work is licensed under a Creative Commons Attribution-NonCommercial 4.0 International License (CC BY-NC 4.0).

* Corresponding author E-mail address: vvd-77@mail.ru 


\title{
К расчету совместимости олигомеров \\ с высокомолекулярными каучуками
}

\author{
В.Д. Ворончихин ${ }^{a}$, М.С. Товбис ${ }^{a}$, \\ С.Ю. Воронина ${ }^{\text {a, }}$, О.В. Карманова \\ ${ }^{a}$ Сибирский государственный университет \\ науки и технологий имени академика М.Ф. Решетнева \\ Российская Федерация, Красноярск \\ ${ }^{6}$ ФИЦ «Красноярский научный изентр СО РАН» \\ Российская Федераџия, Красноярск \\ ${ }^{6}$ Воронежский государственный университет \\ инженерных технологий \\ Российская Федерация, Воронеж
}

Аннотация. В статье представлен модифицированный теоретический расчет параметра растворимости для олигомеров и полимеров, учитывающий влияние их молекулярной структуры. Полученные значения параметра растворимости позволяют прогнозировать термодинамическую совместимость для полимеров и олигомеров.

Ключевые слова: параметр растворимости, полимеры, олигомеры, термодинамическая совместимость.

Цитирование: Ворончихин В.Д., К расчету совместимости олигомеров с высокомолекулярными каучуками / В.Д. Ворончихин, М.С. Товбис, С.Ю. Воронина, О.В. Карманова // Журн. Сиб. федер. ун-та. Химия, 2020. 13(1). С. 3139. DOI: $10.17516 / 1998-2836-0167$

\section{Introduction}

The effect of the structure of the polymer matrix on the technological and technical properties of the compositions is associated with two effects: direct, due to the influence of the chemical structure of polymer macromolecules on the parameters of intra- and intermolecular interactions, and indirect, related to the effect on the conformational state of macromolecules [1].

The intensity of interpenetration in polymer-polymer, polymer-oligomer or oligomer-oligomer mixtures will be determined by the mutual solubility of each component of the system or the solubility parameter $\delta[2,3]$, characterizing the cohesive interaction of the mixed compounds.

If the $\delta$ values of two substances are equal to each other, then they will mutually dissolve and form a true solution. For low molecular weight compounds, such as solvents, this position is confirmed. However, the transition to more complex compounds, such as polymeric materials, does not allow the system to form a true solution. This is due to the structural heterogeneity of the polymer chain, its strictly individual molecular characteristics and other factors affecting the intensity of the intermolecular interaction. As a result, in mixtures containing polymers or oligomers, the formation of a heterogeneous structure with a continuous matrix and phase inclusions is observed. 
In this regard, the aim of the work was to establish the value of the parameter $\delta$ for low and high molecular weight compounds used as the polymer base of elastomeric compositions.

\section{Results and discussion}

For low molecular weight compounds, for example plasticizers of polymeric materials, the theoretical and experimental determination of the solubility parameter is an easily implemented measure [4]. For macromolecular compounds, the traditional approach for determining the specific heat of vaporization is not possible, because polymers do not evaporate without decomposition. As a result, the determination of the solubility parameter for polymer compounds is possible only by the calculation method.

If we use the approach used to calculate the packing density of oligomeric compounds [5] to calculate the solubility parameter of oligomeric compounds [5], which involves taking into account the differences in the micro- and macrostructure of macromolecules (chemical structure, functionality, steric arrangement of repeating units, molecular weight), formula (1) acquires view

$$
\delta=\rho \cdot \frac{\sum F}{M}
$$

where $\rho$ is the polymer density, $\mathrm{g} / \mathrm{cm}^{3} ; M$ is the molecular weight of the repeating unit of the polymer; $\Sigma F$ is the interaction energy of a group of atoms forming a repeating unit of the polymer (molecular attraction constant).

Later, Hoy [6] also presented some values of group contributions for calculating $F$.

The set of similar atomic and group contributions obtained by Van Krevelen [7, 8] for calculating $\Sigma F$ (Table 2) also allows one to calculate the solubility parameter of polymers.

The use of the molecular attraction constant of atoms and chemical groups (Tables 1,2) made it possible to determine the solubility parameter for functional oligodienes [9] used as "temporary" plasticizers for elastomeric compositions and strength modifiers of composite materials (Table 3).

It was found that the calculated values of the solubility parameter for the diene part of the studied oligomers have close values regardless of the proposed method, while the solubility parameters of the polar groups have significant differences (Table 2). Given the reduced molecular weight of oligomeric rubbers and the significant influence of existing functional groups on their properties, this characterizes the limited application of the traditional calculation method for functional oligomeric compounds.

If we use the approach used to calculate the packing density of oligomeric compounds [5] to calculate the solubility parameter of oligomeric compounds, formula (1) takes the form

$$
\delta=\rho \cdot\left(\varphi_{1} \frac{\sum F_{1}}{M_{1}}+\varphi_{2} \frac{\sum F_{2}}{M_{2}}+\varphi_{3} \frac{\sum F_{3}}{M_{3}}+\ldots+\varphi_{i} \frac{\sum F_{i}}{M_{i}}\right)
$$

where $\Sigma F_{i}$ is the sum of the constants of molecular attraction in the $\mathrm{i}$-th functional group or monomer unit; $\varphi_{i}$ is the fraction of the ith functional group or monomer unit in the structure of the molecule.

For the theoretical calculation of the compatibility of high- and low molecular weight polymers, rubbers were selected that are most often used in scientific research and in industry for the manufacture of general and special purpose products. 
Table 1. The constants of molecular attraction of the chemical groups and atoms that make up the functional oligodienes

\begin{tabular}{|c|c|c|c|}
\hline \multirow{2}{*}{ Group or atom } & \multicolumn{3}{|c|}{$\mathrm{F},\left(\mathrm{cal}^{-\mathrm{cm}^{3}}\right)^{0.5} / \mathrm{mol}$} \\
\cline { 2 - 4 } & by Small [5] & by Hoy [6] & by Van Crevelen [7, 8] \\
\hline$-\mathrm{CH}_{3}$ & 214 & 147,3 & - \\
\hline$-\mathrm{CH}_{2}-$ & 133 & 131,5 & - \\
\hline$>\mathrm{C}<$ & -93 & 32,03 & - \\
\hline$=\mathrm{CH}-$ & 111 & 121,53 & - \\
\hline$=\mathrm{CH}{ }_{2}$ & 190 & 126,54 & - \\
\hline$>\mathrm{C}=\mathrm{O}$ & 275 & 262,96 & - \\
\hline$-\mathrm{H}$ & $80-100$ & $-50,47$ & - \\
\hline$-\mathrm{OH}$ & 170,99 & 225,84 & 0 \\
\hline$-\mathrm{C} \equiv \mathrm{N}$ & 410 & 254,56 & 68,5 \\
\hline $\mathrm{C}$ & - & - & 335 \\
\hline $\mathrm{H}$ & - & - & 360 \\
\hline $\mathrm{O}$ (ketone) & - & - & 300 \\
\hline $\mathrm{O}$ (primary alcohol) & - & - & 480 \\
\hline $\mathrm{O}$ (secondary alcohol) & - & - & \\
\hline $\mathrm{N}$ (nitrile) & - & & \\
\hline
\end{tabular}

Table 2. The solubility parameter of the diene base and the functional groups of oxygen-containing oligodienes, calculated by the formula (2)

\begin{tabular}{|c|c|c|c|c|c|c|}
\hline \multirow{3}{*}{ Oligomer } & \multicolumn{6}{|c|}{ The solubility parameter $\delta, \mathrm{cal}^{1 / 2} / \mathrm{cm}^{3 / 2}$} \\
\cline { 2 - 7 } & \multicolumn{2}{|c|}{ by Small } & \multicolumn{2}{c|}{ by Hoy } & \multicolumn{2}{c|}{ by Van Crevelen } \\
\cline { 2 - 7 } & diene base & $\begin{array}{c}\text { functional } \\
\text { group }\end{array}$ & diene base & $\begin{array}{c}\text { functional } \\
\text { group }\end{array}$ & diene base & $\begin{array}{c}\text { functional } \\
\text { group }\end{array}$ \\
\hline SKD-0 & 8,12 & 9,85 & 8,42 & 7,68 & 6,84 & 11,78 \\
\hline SKD-GTRA & 8,42 & 5,75 & 8,73 & 6,65 & 7,09 & 12,69 \\
\hline SKD-9 & 8,56 & 7,98 & 8,87 & 7,78 & 7,01 & 8,83 \\
\hline SKD-KTR & 8,32 & 9,13 & 8,63 & 8,67 & 7,01 & 12,55 \\
\hline
\end{tabular}

The oligomers were selected: low molecular weight polybutadiene of the SKD-0 brand, oligobutadiene with terminal hydroxyl groups (SKD-GTPA), oligobutadiene with terminal carboxyl groups (SKD-KTP) and oligobutadiene with statistically distributed 9 carbonyl groups (SKD) in the chain.

Carbochain rubbers of various polarity and molecular structure were selected as high molecular weight polymers, namely: 1,4-cis-polybutadiene (BR); 1,4-cis-polyisoprene synthesized in the presence of a titanium-based catalyst (SKI-3); 1,4-cis-polyisoprene synthesized in the presence of a catalyst on a niode base (SKI-5); natural rubber brand RRS-1; polychloroprene brand PS-40A; a copolymer of ethylene with propylene and ethylidene norbornene Keltan ${ }^{\circledR 512}$; a copolymer of ethylene with propylene and dicyclopentadiene (SKEPT-50); copolymer of butadiene and $\alpha$-methyl styrene SKMS30ARK; a copolymer of butadiene and $\alpha$-methyl styrene (SBR-1500); a copolymer of butadiene and 
Table 3. The solubility parameter of functional oligodienes and of the main elastomers calculated by the formula (2)

\begin{tabular}{|c|c|c|c|c|}
\hline & \multirow{2}{*}{ Material } & \multicolumn{3}{|c|}{ The solubility parameter $\delta$, $\mathrm{cal}^{1 / 2} / \mathrm{cm}^{3 / 2}$} \\
\hline & & \multirow{2}{*}{$\begin{array}{c}\text { by Small } \\
8,17\end{array}$} & \multirow{2}{*}{$\begin{array}{c}\text { by Hoy } \\
8,41\end{array}$} & \multirow{2}{*}{$\frac{\text { by Van Crevelen }}{6,97}$} \\
\hline \multirow{4}{*}{ 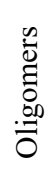 } & SKD-0 & & & \\
\hline & SKD-GTRA & 8,34 & 8,63 & 7,15 \\
\hline & SKD-9 & 8,46 & 8,72 & 7,32 \\
\hline & SKD-KTR & 8,33 & 8,66 & 7,29 \\
\hline \multirow{13}{*}{ 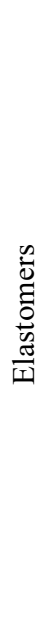 } & $\mathrm{BR}$ & 8,22 & 8,53 & 8,27 \\
\hline & SKI-3 & 8,21 & 8,29 & 8,45 \\
\hline & SKI-5 & 8,25 & 8,34 & 8,50 \\
\hline & PS-40A & 9,03 & 9,44 & 7,76 \\
\hline & SKEPT-50 & 8,21 & 8,12 & 8,70 \\
\hline & Keltan $^{\circledR} 512$ & 7,93 & 7,80 & 8,32 \\
\hline & RRS-1 & 7,72 & 10,80 & 7,94 \\
\hline & SBR-1500 & 7,94 & 6,49 & 6,81 \\
\hline & SBR-1705 & 8,43 & 6,48 & 6,83 \\
\hline & SBR-1723 & 6,62 & 6,66 & 6,86 \\
\hline & NBR-18 & 8,69 & 8,58 & 9,94 \\
\hline & NBR-28 & 9,39 & 9,39 & 7,45 \\
\hline & NBR-40 & 10,29 & 8,86 & 10,37 \\
\hline
\end{tabular}

$\alpha$-methyl-styrene containing 15 wt. $\%$ oil (SBR-1705); a copolymer of butadiene and $\alpha$-methyl-styrene containing 27 wt. \% oil (SBR-1723); a copolymer of butadiene and nitrile of acrylic acid containing 18 wt. \% acrylonitrile (NBR-18); a copolymer of butadiene and nitrile of acrylic acid containing 28 wt. \% acrylonitrile (NBR-28); a copolymer of butadiene and nitrile of acrylic acid containing 40 wt. $\%$ acrylonitrile (NBR-40).

The proposed equation (2) allows us to calculate the solubility parameter of oxygen-containing oligodienes and basic elastomers, taking into account their molecular and structural features (Table 3 ).

In accordance with the Ji rule [11], the maximum degree of compatibility of components with equal values of the Hildebrant solubility parameter of the blended polymers $(\delta \mathrm{A}=\delta \mathrm{B})$.

It was established (Table 3) that each oligomer and elastomer has its own individual value $\delta$. When choosing an oligomer-polymer pair to create durable materials, it is necessary that the difference between the solubility parameters is minimal. So, for example, when using SKD-0 low molecular weight polybutadiene as a "temporary" plasticizer, maximum thermodynamic compatibility will be observed when it is combined with BR, SKI-3, SKI-5, and SKEPT-50 rubbers (Table 3). Significant differences in the value of $\delta$ of oligodiene SKD-0 with rubbers PS-40A, SBR-1723, NBR-18, NBR-28 and NBR-40 (Table 3) clearly demonstrate the thermodynamic incompatibility of these polymers and, as a consequence, the limitations of their joint use.

In addition to theoretical calculations of the degree of compatibility of components in polymer compositions, sufficient experimental material has now been accumulated that reflects the phase state of polymer-polymer mixtures [12]. 
It is known [13-15] that a decrease in the molecular weight of polymers leads to an increase in their compatibility with polymers due to mutual segmental solubility. Taking into account that the segmental solubility of polymers depends on the level of intermolecular interaction [16], it is assumed that the functional groups of oligodienes influence their solubility in high molecular weight compounds, i.e. either increase the compatibility of oligomers with high molecular weight rubbers, or reduce it by increasing or decreasing the solubility of segments conjugated to functional groups. Any changes in the nature of the main chain and functional groups lead to a change in the ratio between the dissolved chain segments and segments conjugated with functional groups, and thereby affect the overall solubility of the oligomers in rubbers.

In real polymer-polymer, polymer-oligomer or oligomer-oligomer mixtures, it is impossible to detect the fulfillment of such an equality. Even insignificant differences in the micro- and macrostructure or chemical structure of molecules of the same type of polymer during the preparation of mixtures will lead to the formation of a heterophase structure of the composite, in which the matrix will be a polymer or an oligomer forming a continuous structure. The magnitude of the phase will be determined by many factors.

As a result, the process of obtaining polymer-polymer, polymer-oligomer or oligomer-oligomer mixtures inevitably comes down to determining the degree of compatibility of the components. In the manufacture of mixtures of components with a similar viscosity level (polymer-polymer or oligomeroligomer) due to intense shear deformations, mixtures with minimal heterophasic structure can be obtained $[13,14]$. It is noted that the higher the viscosity of the mixture, the less phase separation processes are observed.

When combining high and low molecular weight polymers, creating a stable system is a complex process. Creating a mechanical polymer-oligomer mixture with minimal heterophase is a feasible task [13]. Obtaining a thermodynamically stable polymer-oligomer mixture involves taking into account many factors, the main of which is the chemical nature of the mixed components.

Diffusion of the oligomer into the polymer maximally illustrates the thermodynamic compatibility in the polymer-oligomer pairs. The use of the sorption method as a criterion of thermodynamic compatibility [17], i.e. determining the saturation concentration during spontaneous mixing of the oligomer with rubber, made it possible to establish the real level of compatibility of high and low molecular weight polymers of different nature.

The results (Table 4) show that the sorption of low molecular weight rubbers in the studied polymer-oligomer pairs is determined by the nature of the main chain of high molecular weight rubber and oligomer, the type and location of functional groups in oligodien. In this case, the functional groups of oligomers affect the segmental solubility of the conjugated segments of the molecular chain.

The obtained results show (Table 4) that the oligomer SKD-9 in the polar rubbers NBR-18, NBR-28, NBR-40, polychloroprene PS-40A and non-polar SKEPT-50 and Keltan ${ }^{\circledR} 512$ possess the maximum segmental solubility.

The oligomer SKD-0 does not contain functional groups in its structure and is a nonpolar compound; it exhibits maximum segmental diffusion with respect to rubbers BR, SKI-3, SKI-5, SBR-1500, SBR-1705, SBR-1723 (Table 4). It was noted (table. 4) that the oligomers SKD-KTR and SKD-GTRA, penetrating the bulk of the rubber sample SBR-1723, dissolve the PN-6k softener 
Table 4. Sorption (\%) of high molecular weight rubbers of functional oxygen-containing oligomers

\begin{tabular}{|c|c|c|c|c|}
\hline \multirow{2}{*}{$\begin{array}{c}\text { Type of high } \\
\text { molecular weight } \\
\text { rubber }\end{array}$} & SKD-0 & SKD-GTRA & SKD-KTR & SKD-9 \\
\cline { 2 - 5 } & 17,6 & 20,8 & 13,5 & 19,6 \\
\hline RRS-1 & 28,7 & 7,7 & 11,7 & 19,4 \\
\hline SKI-3 & 28,9 & 6,3 & 13,1 & 17,7 \\
\hline SKI-5 & 33,6 & 2,3 & 5,9 & 8,1 \\
\hline BR & 42,4 & 6,7 & 7,1 & 19,6 \\
\hline SBR-1500 & 26,6 & 1,2 & 5,8 & 10,3 \\
\hline SBR-1705 & 23,6 & $-5,1$ & $-3,8$ & 24,8 \\
\hline SBR-1723 & 9,3 & 11,7 & 11,5 & 37,5 \\
\hline Keltan ${ }^{\circledR} 512$ & 8,7 & 11,4 & 17,9 & 50,6 \\
\hline SKEPT-50 & 23,2 & 22,1 & 27,8 & 18,2 \\
\hline NBR-18 & 6,0 & 4,7 & 8,9 & 66,1 \\
\hline NBR-28 & 15,6 & 22,6 & 40,3 & 28,7 \\
\hline NBR-40 & 14,1 & 8,7 & 11,4 & \\
\hline PS-40A & & & & \\
\hline
\end{tabular}

contained in it. This indicates that the oligomers SKD-KTR and SKD-GTRA have a high affinity for styrene-butadiene rubber compared to PN-6k paraffin-naphthenic oil.

Comparison of the results of theoretical calculations of $\delta$, for example, for the polar oligomers SKD-9, SKD-KTR and SKD-GTR, and the polar rubber NBR-28, shows that a decrease in the difference between the $\delta_{\text {polymer }}$ and $\delta_{\text {oligomer }}$ (regardless of their calculation method) increases the level of sorption of low molecular weight rubbers high molecular weight (Fig. 1). The maximum sorption of the oligomer SKD-9 by the rubber NBR-28 is observed (Fig. 1). The minimal sorption of the less polar SKD-GTPA oligodiene, in turn, is caused by a larger difference in the parameters $\delta$ (Fig. 1).

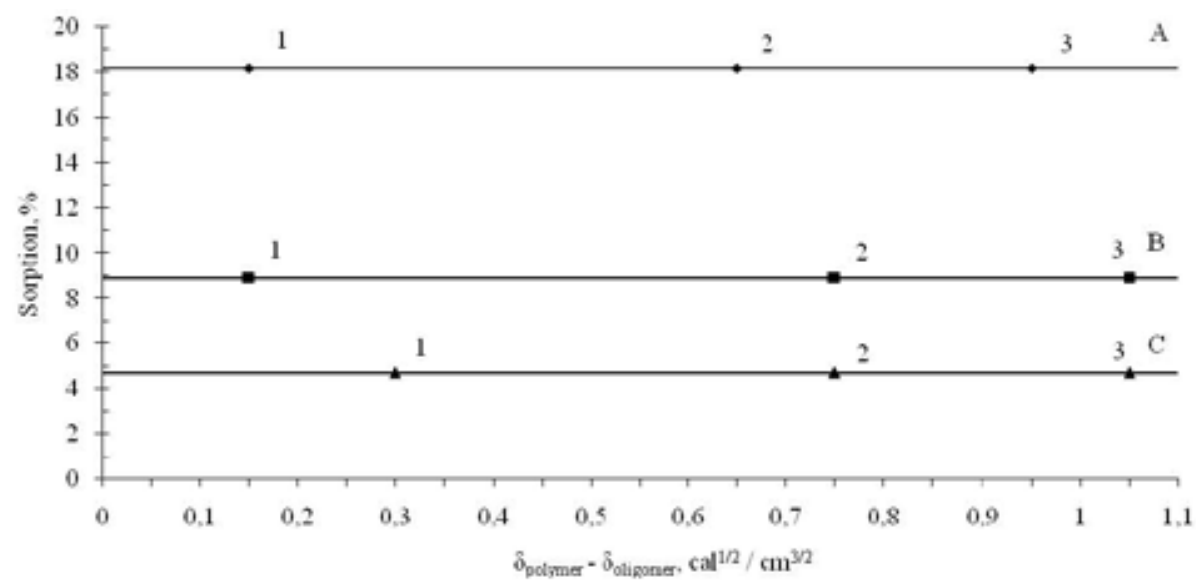

Fig. 1. The sorption level of functional oligolienes SKD-9 (A), SKD-KTR (B) and SKD-GTR (C) with NBR-28 rubber, depending on the difference of the $\delta_{\text {polymer }}-\delta_{\text {oligomer }}$ calculated by the Small method (point 1), Hoy (points 2) and according to the Van Crevelen method (points 3) 


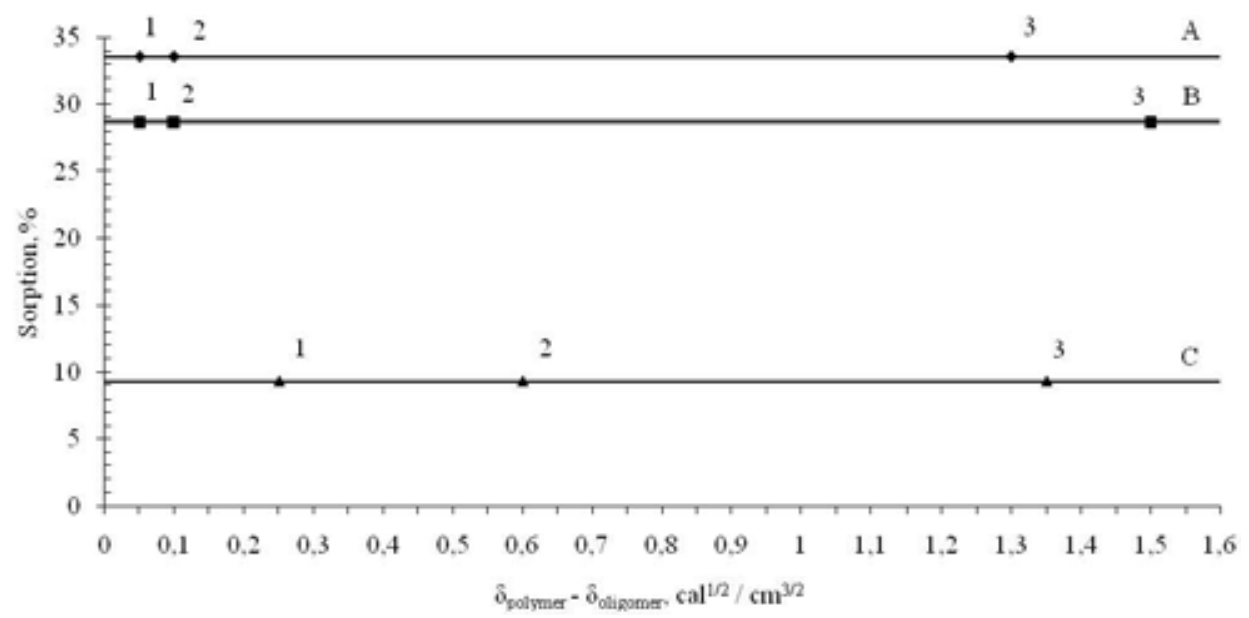

Fig. 2. The sorption level of low molecular weight polybutadiene SKD-0 with rubbers BR (A), SKI-3 (B) and Keltan ${ }^{\circledR} 512(\mathrm{C})$ depending on the difference of the $\delta_{\text {polymer }}-\delta_{\text {oligomer }}$ calculated by the Small method (point 1$)$, Hoy (points 2) and according to the Van Crevelen method (points 3)

A decrease in the difference between the $\delta_{\text {polymer }}$ and the $\delta_{\text {oligomer }}$ (regardless of the method of their calculation) for non-polar rubbers and SKD-0 oligodiene also provides an increase in the level of sorption of low molecular weight rubber by high molecular weight. For example, the maximum sorption of SKD-0 low molecular weight rubber is observed by its high molecular weight analogue, BR high molecular weight rubber, and the minimum sorption by Keltan ${ }^{\circledR} 512$ (Fig. 2).

Taking into account the obtained $\delta$ values for high and low molecular weight rubbers, and also taking into account the experimentally determined solubility of the SKD-0 oligomer in the matrix of non-polar rubbers and the high diffusion activity of the SKD-9 oligoketone with respect to polar polymers, it is assumed that they will have a greater effect on the phase organization and nature of the structure formation of polymer-oligomeric composites, in comparison with the oligomers SKD-KTR and SKD-GTRA, thereby ensuring the creation of products with an increased resource operation.

The results obtained demonstrate the possibility of applying formula (2) for a more accurate calculation of the thermodynamic compatibility of a high molecular weight matrix with various polymers and processing aids used to create a wide range of polymer composite materials.

\section{Acknowledgements / Благодарности}

This work was carried out upon the implementation of project № 05.607.21.0310 in the framework of event 1.3 «Conducting applied research and development aimed at creating products and technologies» of the federal target program «Research and development in priority areas for the development of the scientific and technological complex of Russia for 2014-2020».

Работа выполнена при реализации проекта № 05.607.21.0310 в рамках мероприятия 1.3 «Проведение прикладных научных исследований и разработок, направленных на создание продукции и технологий» программы ФЦП «Исследования и разработки по приоритетным направлениям развития научно-технологического комплекса России на 2014-2020 годы». 


\section{References}

1. Myagchenkov V.A., Frenkel S.Ya. Compositional heterogeneity of copolymers. L.: Chemistry, 1988. 248 p. (In Russ.)

2. Hildebrand J.H., Scott R.L. The Solubility of Nonelectrolites. New York: Reinold Publ. Corp., 1950. $355 \mathrm{p}$.

3. Hildebrand J.H., Prausnitz J.M., Scott R.L. Regular and Related Solutions. New York: Van Nostrand, 1970. 377 p.

4. Nigmatullina A.I., Sharipov E.N., Okhotina N.A. Determination of solubility and compatibility with Picard hydrocarbon rubbers. Advances in Chemistry and Chemical Technology 2007. Vol. 21 (6 (74)), P. 37-40. (In Russ.)

5. Voronchikhin V.D., Shabunina N.A., Dubkov K.A., Ivanov D.P., Semikolenov S.V. About Density of Packing of Oligomer Connections. Journal of Siberian Federal University. Chemistry 2014. Vol. 7 (2), P. 236-241. (In Russ.)

6. Hoy K.L. New Values of the Solubility Parameters from Vapor Pressure Data. Journal of Paint Technology 1970. Vol. 42 (541), P. 76-118.

7. Van Krevelen D.W. Chemical Structure and Properties of Coal. XXVIII. Coal Constitution and Solvent Extraction. Fuel 1965. Vol. 44 (4), P. 229-242.

8. Van Krevelen D.W., Hoftyzer P.J. Properties and polymers correlation with chemical structure. Elsevier Publ. Comp., Amsterdam-London-New York, 1972. 427 p.

9. Shabunina N.A., Voronchikhin V.D., Lesik E.I., Berestyuk A.V., Karmanova O.V., Shutilin Yu.F. A comparative study of the structure and properties of certain types of oligodienes. Rubber and Rubber 2017. Vol. 76 (2), P. 74-77. (In Russ.)

10. Small P.A. Factors Affecting the Solubility of Polymers. Journal of Applied Chemistry 1953. Vol. 3 (2), P. 71-80.

11. Gee D. Thermodynamic study of solutions and gels of rubbery polymers. Chemistry of large molecules: Sat. No. 1. High molecular weight compounds. M.: State. publishing house in. lit., 1948 - P. 137-202. (In Russ.)

12. Chalykh A.E., Gerasimov V.K., Mikhailov Yu.M. Phase diagrams of polymer systems. M.: Janus-K, 1998. 103 p. (In Russ.)

13. Kuleznev V.N. Mixtures of polymers. M.: Chemistry, 1980. 304 p. (In Russ.)

14. Bespalov Yu.A., Konovalenko N.G. Multicomponent systems based on polymers. L.: Chemistry, 1981. 88 p. (In Russ.)

15. Manson J.A., Sperling L.H. Polymer blends and composites. Plenum Press, New York, 1976. $513 \mathrm{p}$.

16. Kuleznev V.N. Mixtures and alloys of polymers. SPb.: NOT, 2013. 216 p. (In Russ.)

17. Nesterov Yu.M., Ogrel A.M., Kiryukhin N.N., Krakshin M.A. Direct determination of the compatibility of oligomers with rubbers by sorption. Rubber and Rubber 1990. No. 7, P. 20-21. (In Russ.) 